\title{
Effect of ethanol leaching conditions on the properties of liqueur prepared from Citrus junos fruit peels
}

\author{
Hun-Sik Chung*, Han-Sol Park, Han-Soo Kim, Young-Guen Lee, Jong-Hwan Seong \\ Department of Food Science and Technology, Pusan National University, Miryang 50463, Korea
}

\section{유자 과피의 담금 조건이 침출주의 품질특성에 미치는 영향}

\author{
정헌식*·박한솔·김한수·이영근·성종환 \\ 부산대학교 식품공학과
}

\begin{abstract}
This study was conducted to prepare liqueur using Citrus junos fruit peels. Effects of ethanol concentration (EC) and mixing ratio (MR) of leaching solvents with fruit peels on the quality characteristics of the liqueur were investigated. Sliced peels separated from $C$. junos with an MR of $\mathbf{2 5 \%}$ were placed in glass jars and mixed with leaching solvents with ECs of $10 \%, 20 \%, 30 \%, 40 \%$, or $50 \%$. Additionally, sliced peels with MRs of $5 \%, 15 \%, 25 \%, 35 \%$, or $\mathbf{4 5 \%}$ were placed in glass jars, mixed with a leaching solvent with an EC of $30 \%$, and then leached for 30 days at $20^{\circ} \mathrm{C}$. As the $\mathrm{EC}$ increased, the soluble solid and vitamin $\mathrm{C}$ contents of the liqueur decreased slightly, while the phenolic compound content increased. The soluble solid content, titratable acidity, phenolic compound content, vitamin $C$ content, antioxidant activity, and color properties $\left(-a^{*}\right.$ value, $b^{*}$ value) increased linearly with increasing MR. From these results, it was confirmed that $C$. junos fruit peels could be used to produce liqueur. It was concluded that an MR of $45 \%$ or more was suitable for liqueur production.
\end{abstract}

Key words : Citrus junos, liqueur, fruit peel, ethanol, leaching

\section{서 론}

유자나무(Citrus junos)는 동아시아 지역이 원산지와 주 재배지이고, 귤속 식물 중 내한성과 내병성이 비교적 강한 상록관목이며, 그 열매는 과피가 두껍고 표면이 울퉁불퉁 하며 종자가 많고 강한 산미와 고유한 향을 가져 직접 생식 용보다는 당절임차 형태로 주로 소비되고 있다(1). 최근 들어 유자 과실의 면역력 증진 및 미백 효과 $(2,3)$, 과피의 항산화 효과(4), 종실의 항비만, 항산화 및 항암 효과(5-7), 정 유의 항아토피 효과(8) 등의 건강 기능성이 알려지면서 유자의 고부가가치화와 가공제품의 다양화에 대한 관심이 증대되고 있다.

*Corresponding author. E-mail : hschung@pusan.ac.kr Phone : 82-55-350-5352, Fax : 82-55-350-5350

Received 20 December 2018; Revised 07 January 2019; Accepted 25 January 2019.

Copyright (c) The Korean Society of Food Preservation. All rights reserved.
유자 과실의 가공에 관한 연구로서, 과즙 관련으로는 착 즙방법별 과즙의 품질특성 조사 $(9,10)$, 과즙 식초(11)와 분 말(12) 제조, 과즙을 첨가한 양파발효음료(13), 마요네즈 (14), 된장(15), 소스(16), 과편(17), 아이스크림(18), 젤리 (19) 등의 제조와 착즙박의 펙틴 추출(20)이 있다. 그리고 과피 관련으로는 과피 침출차(21) 제조와 과피 소량첨가 막걸리(22), 진양주(23), 쿠키(24), 소시지(25) 제조 및 과피 로부터 올레오레진(26) 제조와 초임계 이산화탄소 이용 휘 발성 정유(27) 추출 등이 있다. 또한 과실 첨가 동치미(28)와 초콜릿(29) 제조와 냉동과실을 이용한 잼(30) 제조, 당알코 올류 첨가 유자차(31) 제조, 유자청 첨가 발아현미다식(32) 과 설기떡(33) 제조 등이 보고된 바 있다. 이상과 같이 유자 의 활용 관련 연구들이 다수 수행되어 유용한 결과를 얻은 바 있고, 제주산 감귤류 과피를 이용한 침출주(liqueur) 제조 를 위한 연구 보고(34)와 이탈리아에서 레몬 과피를 원료로 한 침출주의 일종인 'Limoncello'가 생산되는 것을 볼 때 (35) 유자 과피의 경우도 약효성분과 고유 향을 최대한 살릴 수 있는 지역 특산 침출주 제조가 가능할 것으로 생각된다. 
침출주는 에탄올과 물을 이용하여 재료에 함유된 유효성 분이 침출되게 하는 주류제조의 한 방법으로 만든 제품이며 다양한 원료의 침출주 제조 관련 연구가 수행되었으며, 침 출조건에 따른 감귤류(34), 참다래(36), 매실(37), 더덕(38), 화류(39), 약초(40), 커피(41) 등의 품질특성 분석 결과들이 보고된바 있다. 그러나 유자 과실은 물론 과피를 활용한 침출주 제조에 관한 연구결과는 거의 찾아보기 힘든 실정이 다.

따라서 본 연구에서는 유자 과실의 고부가가치화와 가공 제품의 다양화의 일환일 수 있는 침출주 제조에 유용한 기본 정보를 얻고자, 유자 과피를 이용한 주정 침출주 제조 와 그의 이화학적 품질특성에 침출조건인 에탄올 농도와 침출 용매 대비 유자 과피 담금 비율이 미치는 영향을 조사 하였다.

\section{재료 및 방법}

\section{재 료}

실험용 유자과실은 2016년 11월 15일 경상남도 남해군에 서 수확한 '남해재래' 품종을 다음 날 배송 받아 크기와 표면색도가 균일한 과실만 선별, 수세하고 과피와 과육을 분리한 후 과피 만을 사용하였다. 이때 과실 한 개당 평균 무게는 $162 \pm 17 \mathrm{~g}(\mathrm{n}=50)$ 이었고 이 중 과피가 차지하는 비율 은 약 $42 \pm 2 \%$ 이었다.

\section{침출주 제조}

유자 과피를 8 등분하여 광구 유리병에 넣고 여기에 발효 주정(Daehan Ethanol Co., Seoul, Korea)을 희석한 에탄올 농도 $10 \%, 20 \%, 30 \%, 40 \%, 50 \%(\mathrm{v} / \mathrm{v})$ 의 침출용매를 용매 대비 시료 담금 비율이 $25 \%(\mathrm{w} / \mathrm{v})$ 가 되게 넣은 조건과 에탄 올 농도 $30 \%(\mathrm{v} / \mathrm{v})$ 의 침출용매를 용매 대비 시료 담금 비율 이 $5 \%, 15 \%, 25 \%, 35 \%, 45 \%(\mathrm{w} / \mathrm{v})$ 가 되게 넣은 조건으로 구분하고 $20^{\circ} \mathrm{C}$ 에서 1 개월 동안 침출실험을 실시한 후 침출 주의 품질특성에 에탄올 농도가 미치는 영향과 용매 대비 시료 담금 비율이 미치는 영향을 각각 조사하였다. 이때 적용한 에탄올 농도 범위는 시중 유통 주류의 에탄올 농도 를 바탕으로 설정하였고, 침출기간은 감귤류의 기존보고 (34)를 참고하여 설정하였다.

\section{가용성 고형분 함량 측정}

가용성 고형분 함량은 침출주 시료액 $5 \mathrm{~mL}$ 를 칭량접시에 담아 건조기(VS-1202D3N, Vision Scientific Co., Ltd., Bucheon, Korea)로 $105^{\circ} \mathrm{C}$ 에서 항량 도달 때까지 건조시킨 후 잔류물의 무게를 측정하였다.

\section{적정산도 측정}

적정산도는 침출주 시료액을 일정비로 희석하고 그 액 $20 \mathrm{~mL}$ 취해 $0.1 \mathrm{~N} \mathrm{NaOH}$ 용액으로 $\mathrm{pH} 8.0$ 이 될 때까지 적정하여 소비된 $\mathrm{mL}$ 수를 citric acid로 환산하여 나타내었 다.

\section{총 페놀 함량 측정}

총 페놀 함량은 침출주 시료액을 취해 Folin-Ciocalteu법 (42)으로 측정하였다. 즉, 침출주 시료액 $2 \mathrm{~mL}$ 를 취하여 Folin-Ciocalteu reagent $2 \mathrm{~mL}$ 를 가하고 3 분간 정치한 다음 $10 \% \mathrm{Na}_{2} \mathrm{CO}_{3}$ 용액 $2 \mathrm{~mL}$ 를 가하였다. 이 혼합액을 1 시간 동안 정치한 후 spectrophotometer(UV1800, Shimadzu, Kyoto, Japan)를 이용하여 $760 \mathrm{~nm}$ 에서 흡광도를 측정하였고, caffeic acid 표준품으로 검량선을 작성하여 정량하였다.

\section{총 비타민 $\mathrm{C}$ 함량 측정}

총 비타민 $\mathrm{C}$ 함량은 침출주 시료액을 취해 $5 \%$ metaphosphoric acid로 희석한 후 2,4-initrophenylhydrazine 비색법(43)으로 측정하였다.

\section{$\mathrm{DPPH}$ 유리기 소거능 측정}

침출주 시료액의 1,1-diphenyl-2-picrylhydrazyl(DPPH) radical scavenging activity는 Blois법(44)으로 측정하였다. 즉, 시료액 $2 \mathrm{~mL}$ 에 에탄올에 용해한 $0.2 \mathrm{mmol} / \mathrm{L} \mathrm{DPPH}$ 용액 $2 \mathrm{~mL}$ 가하고 10 초간 강하게 진탕하고 30 분간 정치한 후에 spectrophotometer(UV1800, Shimadzu)를 이용하여 $517 \mathrm{~nm}$ 에서 흡광도를 측정하였다. DPPH 유리기 소거능은 다음 식으로 계산하였다. DPPH 유리기 소거능(\%)=[1-(시 료액의 흡광도/DPPH 용액의 흡광도 $) \times 100]$.

\section{색도 측정}

색도는 분광측색계(CM-5, Konika Minolta Inc., Tokyo, Japan)를 사용하여 투과색의 $\mathrm{CIE} \mathrm{L}^{*}, \mathrm{a}^{*}, \mathrm{~b}^{*}, \mathrm{~h}^{\circ}, \mathrm{C}^{*}$ 값을 각각 측정하였다. $\mathrm{L}^{*}$ 값은 lightness를, $+\mathrm{a}^{*}$ 와 $-\mathrm{a}^{*}$ 값은 redness 와 greenness를, $+b^{*}$ 와 $-b^{*}$ 값은 yellowness와 blueness를 각 각 나타낸다. $\mathrm{h}^{\circ}$ 값은 색상(red-purple: $0^{\circ}$, yellow: $90^{\circ}$, bluish-green: $180^{\circ}$, blue: $270^{\circ}$ )을 나타내고, $a>0, b>0$ 이면 $\mathrm{h}^{\circ}=\tan ^{-1}(\mathrm{~b} / \mathrm{a})$ 로, $\mathrm{a}<0, \mathrm{~b}>0$ 이면 $\mathrm{h}^{\circ}=180^{\circ}+\tan ^{-1}(\mathrm{~b} / \mathrm{a})$ 으로 각각 계산된다.

\section{통계처리}

실험결과는 3회 반복실험의 평균표푸눞ㄴ차로 나타내었 고, IBM SPSS statistics(23, IBM Corp., Armonk, NY, USA) 를 이용하여 분산분석과 Duncan's multiple range test $(\mathrm{p}<0.05)$ 를 실시하였다. 


\section{결과 및 고찰}

에탄올 농도가 침출주의 품질특성에 미치는 영향

유자 과피의 담금 비율을 $25 \%$ 로 고정하고 침출용매의 에탄올 농도(10-50\%)에 따른 침출주의 가용성 고형분 함량 과 적정산도를 측정한 결과는 Table 1에 나타낸 바와 같다. 가용성 고형분 함량은 전반적으로 $2.19-2.39 \mathrm{mg} / 100 \mathrm{~mL}$ 범위를 보였고 에탄올 농도 $40 \%$ 이상에서 다소 낮은 수준 이었다. 이는 침출용매의 에탄올 농도 증가에 따른 극성 감소에 기인된 결과로 여겨진다 $(34,45)$. 감귤류 과피 침출 주의 경우에도 에탄올 농도 $30 \%$ 보다 $60 \%$ 에서 낮은 가용성 고형분 함량을 보였다고 알려져 있다(34). 유자 과피 침출주 의 적정산도는 에탄올 농도별 유의적인 차이를 보이지 않 고, $51.20-56.53 \mathrm{mg} / 100 \mathrm{~mL}$ 범위를 보였다. 반면에 감귤류 과피 침출주는 에탄올 농도가 $30 \%$ 에서 $95 \%$ 까지 증가할수 록 $\mathrm{pH}$ 가 높아지고 매실 침출주의 유기산 함량은 에탄올 $30-60 \%$ 범위 내에서 고농도 일수록 높은 경향이었다는 보 고도 있다(34,37).

침출용매의 에탄올 농도(10-50\%)에 따른 유자 과피 침출 주의 총 페놀 함량, 총 비타민 C 함량, $\mathrm{DPPH}$ 유리기 소거능 및 색도 값 $\left(\mathrm{L}^{*},-\mathrm{a}^{*}, \mathrm{~b}^{*}\right)$ 를 조사한 결과는 Table 1에 나타내었 다. 총 페놀 함량은 전반적으로 $37.23-44.17 \mathrm{mg} / 100 \mathrm{~mL}$ 범위 내에서 에탄올 농도가 높을수록 높은 경향을 보였다. 이와 유사한 결과로서, 매실 침출주의 총 페놀 함량의 경우 침출 용매의 에탄올 농도가 $45 \%$ 보다 $60 \%$ 에서 높았다는 보고 (37)와 머루의 에탄올 추출에서 에탄올 농도 $50 \%$ 까지는 농도에 비례하여 총 페놀 함량이 높았다는 보고(46)가 있다. 비타민 C 함량은 에탄올 농도가 높아짐에 따라 낮아지는 경향을 보였다. 이는 앞서 언급한 가용성 고형분 함량에서 와 마찬가지로 추출용매의 극성 변화에 따른 비타민 $\mathrm{C}$ 의 용해도 감소에 기인된 결과로 생각된다 $(34,45) . \mathrm{DPPH}$ 유리 기 소거능은 에탄올 농도별 다소 차이는 보였으나 에탄올 농도 증감에 따른 뚜렷한 변화 경향은 보이지 않고,
17.95-28.39\% 범위를 보였다. 색도는 에탄올 농도에 대응하 는 뚜렷한 경향성을 보이지 않고 $\mathrm{L}^{*}$ 값 97.50-98.05, $\mathrm{a}^{*}$ 값 -6.16--7.91, b* 값 21.57-26.13을 각각 나타내었다.

이러한 결과를 볼 때, 침출용매의 에탄올 농도가 침출주 의 이화학적 특성에 미치는 영향이 크지 않지만, 에탄올 농도 $10 \%$ 에서 $50 \%$ 까지 증가함에 따라 유자 과피 침출주의 가용성 고형분과 비타민 $\mathrm{C}$ 함량은 약간 감소하고, 반면에 총페놀 함량은 약간 증가하는 것으로 나타나 상호 상쇄효과 를 감안할 때 유자과피 침출주 제조에 적합한 에탄올 농도 는 약 $30 \%$ 정도인 것으로 판단된다.

\section{과피 담금 비율이 침출주의 품질특성에 미치는 영향}

에탄올 농도가 $30 \%$ 인 용매에 유자 과피의 담금 비율 (5-45\%)를 달리한 침출주의 적정산도와 가용성 고형분 함 량을 측정한 결과는 Fig. 1에 나타내었다. 침출주의 적정산 도와 가용성 고형분 함량은 과피 비율이 증가함에 따라

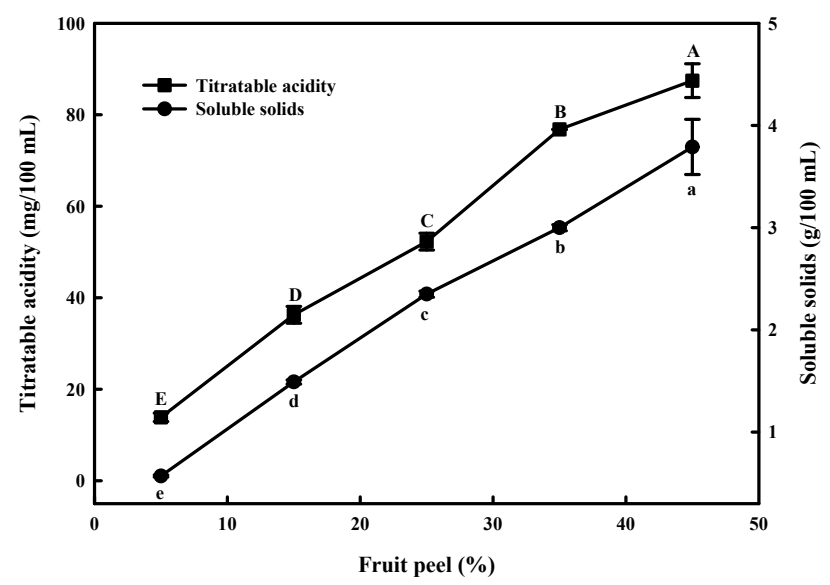

Fig. 1. Soluble solids content and titratable acidity of liqueur prepared from Citrus junos fruit peels as affected by fruit peel level. Means \pm SD ( $n=3$ ) with the same letter above/below the symbol are not significantly different by Duncan's multiple range test $(\mathrm{p}<0.05)$.

Table 1. Physicochemical properties of liqueur prepared from Citrus junos fruit peels as affected by ethanol concentration

\begin{tabular}{|c|c|c|c|c|c|}
\hline \multirow{2}{*}{ Property } & \multicolumn{5}{|c|}{ Ethanol concentration (\%) } \\
\hline & \multirow{2}{*}{$\frac{10}{2.39 \pm 0.05^{\mathrm{al})}}$} & \multirow{2}{*}{$\frac{20}{2.28 \pm 0.03^{\mathrm{b}}}$} & \multirow{2}{*}{$\frac{30}{2.35 \pm 0.04^{\mathrm{a}}}$} & \multirow{2}{*}{$\frac{40}{2.22 \pm 0.02^{\mathrm{bc}}}$} & \multirow{2}{*}{$\frac{50}{2.19 \pm 0.05^{\mathrm{c}}}$} \\
\hline Soluble solids $(\mathrm{g} / 100 \mathrm{~mL})$ & & & & & \\
\hline Titratable acidity $(\mathrm{mg} / 100 \mathrm{~mL})$ & $55.46 \pm 9.77^{\mathrm{a}}$ & $56.53 \pm 1.84^{\mathrm{a}}$ & $52.26 \pm 1.84^{\mathrm{a}}$ & $56.53 \pm 1.84^{\mathrm{a}}$ & $51.20 \pm 6.40^{\mathrm{a}}$ \\
\hline Phenolic compounds $(\mathrm{mg} / 100 \mathrm{~mL})$ & $37.58 \pm 2.17^{b}$ & $37.23 \pm 4.92^{b}$ & $40.95 \pm 0.34^{\mathrm{ab}}$ & $39.49 \pm 0.40^{\mathrm{ab}}$ & $44.17 \pm 1.83^{\mathrm{a}}$ \\
\hline Vitamin C $(\mathrm{mg} / 100 \mathrm{~mL})$ & $23.91 \pm 1.45^{\mathrm{a}}$ & $21.43 \pm 0.98^{b}$ & $21.03 \pm 1.52^{\mathrm{b}}$ & $19.43 \pm 1.47^{\mathrm{b}}$ & $15.84 \pm 1.35^{\mathrm{c}}$ \\
\hline DPPH activity (\%) & $21.28 \pm 4.10^{\mathrm{b}}$ & $22.26 \pm 0.85^{\mathrm{b}}$ & $17.95 \pm 0.85^{b}$ & $28.39 \pm 1.88^{\mathrm{a}}$ & $19.45 \pm 1.80^{\mathrm{b}}$ \\
\hline \multirow{3}{*}{$\begin{array}{l}\text { Color } \\
\text { values }\end{array}$} & $97.81 \pm 0.26^{\mathrm{a}}$ & $98.05 \pm 0.13^{\mathrm{a}}$ & $97.50 \pm 0.05^{\mathrm{b}}$ & $97.95 \pm 0.09^{\mathrm{a}}$ & $97.75 \pm 0.15^{\mathrm{ab}}$ \\
\hline & $-7.91 \pm 0.77^{\mathrm{c}}$ & $-6.68 \pm 0.15^{\mathrm{ab}}$ & $-6.16 \pm 0.27^{\mathrm{a}}$ & $-7.10 \pm 0.19^{b}$ & $-6.18 \pm 0.30^{\mathrm{a}}$ \\
\hline & $26.13 \pm 2.06^{\mathrm{a}}$ & $22.48 \pm 0.80^{b c}$ & $22.23 \pm 1.05^{b c}$ & $24.08 \pm 0.36^{b}$ & $21.57 \pm 0.61^{\mathrm{c}}$ \\
\hline
\end{tabular}

\footnotetext{
${ }^{1)}$ Means $\pm \mathrm{SD}(\mathrm{n}=3)$ in the same row followed by same letter are not significantly different by Duncan's multiple range test $(\mathrm{p}<0.05)$.
} 
거의 선형적으로 증가함을 보였다. 이는 과피 비율이 보다 높은 침출구에서 과피로부터 유기산과 유리당 등의 가용성 물질의 용출량이 많아진 결과에 기인된 것으로 생각된다. 유자 과피에는 유기산으로 citric acid, malic acid, oxalic acid 등이, 유리당으로 fructose, glucose, sucrose 등이 함유 되어 있는 것으로 알려져 있다(47,48). 더덕 침출주(38)의 경우도 더덕 담금 비율이 증가할수록 총당과 환원당 및 불휘발성 성분 함량이 높았고, 매실 침출주(37)도 매실 담금 비율이 증가할수록 유리당과 환원당 함량 및 적정산도가 높았다는 보고가 있다.

페놀성 물질과 비타민 $\mathrm{C}$ 는 대표적인 항산화 물질로 알려 져 있어 그 함량은 식품의 건강 기능성 평가에 주요 지표로 활용되고 있다. 유자 과피의 담금 비율에 따른 침출주의 총 페놀 함량과 총 비타민 $\mathrm{C}$ 함량을 측정한 결과는 Fig. 2 에 나타내었다. 침출주의 총 페놀과 총 비타민 $\mathrm{C}$ 함량은 유자 과피의 담금 비율이 증가함에 따라 정비례하여 높아지 는 패턴을 보였다. 이러한 결과는 유자 과피 첨가 비율이 높은 조건에서 페놀과 비타민 $\mathrm{C}$ 의 침출 양이 많았기 때문인 것으로 생각된다. 한편 더덕과 매실 침출주의 경우도 각각 의 담금 비율이 높을수록 총 페놀 함량이 높았다는 보고 $(37,38)$ 가 있다.

항산화능 평가의 척도로 $\mathrm{DPPH}$ 유리기 소거능을 측정하

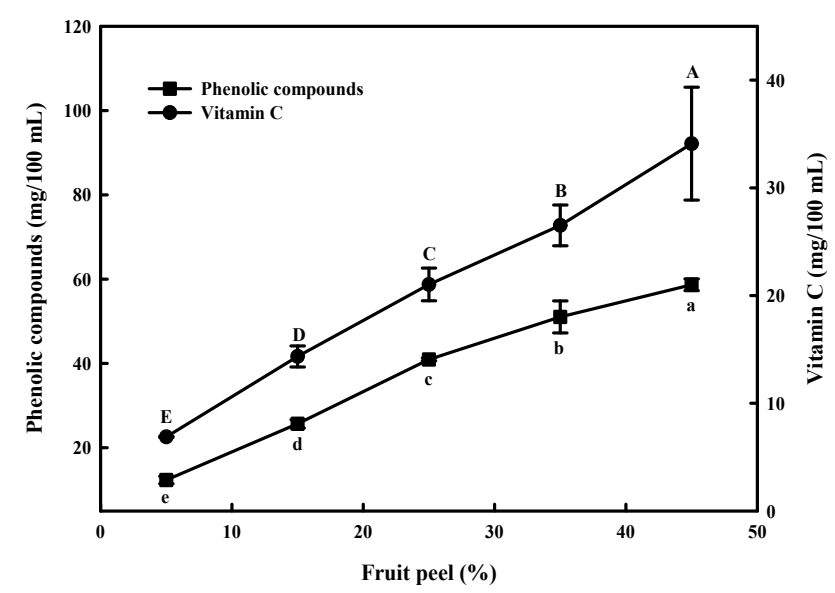

Fig. 2. Phenolic compounds and vitamin $\mathrm{C}$ contents of liqueur prepared from Citrus junos fruit peels as affected by fruit peel level. Means \pm SD ( $n=3$ ) with the same letter above/below the symbol are not significantly different by Duncan's multiple range test $(\mathrm{p}<0.05)$.
였으며(41), 유자 과피의 담금 비율에 따른 그 결과는 Fig. 3과 같다. 침출주의 DPPH 유리기 소거능은 유자 과피 담금 비율의 증가와 더불어 선형적으로 증가함을 보였다. 이는 앞서 언급한 항산화능 원인 물질로 알려진 페놀성 물질과 비타민 C의 용출량 증가에 기인된 결과로 여겨진다(Fig. 2).

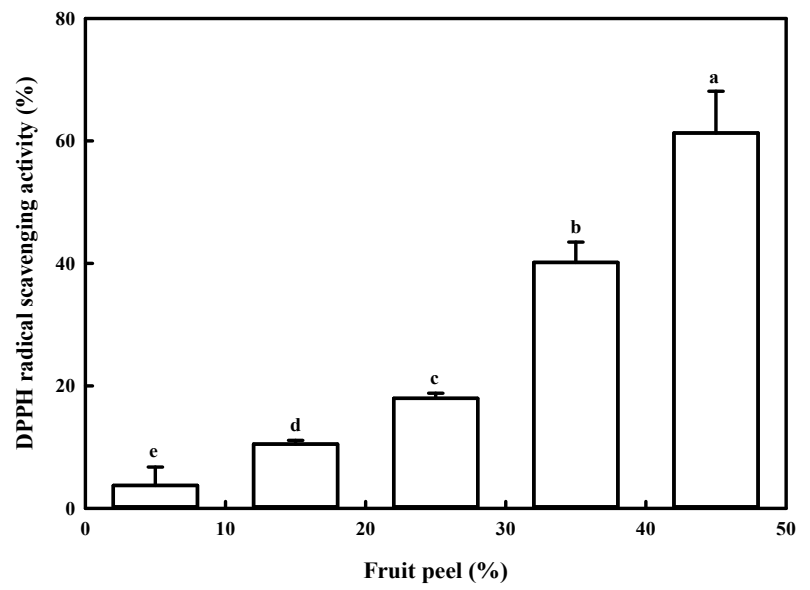

Fig. 3. DPPH radical scavenging activity of liqueur prepared from Citrus junos fruit peels as affected by fruit peel level.

Means \pm SD ( $\mathrm{n}=3$ ) with the same letter above the bar are not significantly different by Duncan's multiple range test $(\mathrm{p}<0.05)$.

유자 과피의 담금 비율에 따른 침출주의 색도를 비교한 결과는 Table 2 와 같다. 침출주의 명도를 의미하는 $\mathrm{L}^{*}$ 값은 과피의 담금비가 낮을수록 높은 경향을 나타내었으나 큰 차이는 없었다. 녹색도를 의미하는 -a* 값은 과피의 담금비 가 높을수록 선형적으로 증가하는 패턴을 보였다. 황색도 를 의미하는 $\mathrm{b}^{\star}$ 값도 과피의 담금비에 정비례하여 증가하는 경향을 나타내었다. 이는 유자 과피에 함유된 녹색과 황색 색소성분의 침출정도 차이에 기인된 것이며, 침출주의 색 도에 과피의 담금 비율이 크게 영향을 미치는 것을 뒷받침 한다. 한편, 더덕 침출주의 경우도 더덕 담금 비율에 비례하 여 황색도가 증가하였으며 이로 인해 높은 관능적 기호도를 가진다고 하였다(38).

이상의 결과를 종합해 보면, 유자 과피 침출주 제조에 있어 용매 대비 과피 담금 비율은 침출주의 이화학적 품질 특성에 큰 영향을 미치는 것으로 확인되었다. 유자 과피의 산도, 가용성 고형분, 총 페놀, 총 비타민 C 함량, 항산화능

Table 2. Color properties of liqueur prepared from Citrus junos fruit peels as affected by fruit peel level

\begin{tabular}{cccccc}
\hline Color & \multicolumn{5}{c}{ Fruit peel (\%) } \\
\cline { 2 - 6 } property & 5 & 15 & 25 & 35 & 45 \\
\hline $\mathrm{L}^{*}$ value & $99.49 \pm 0.03^{\mathrm{al})}$ & $98.55 \pm 0.02^{\mathrm{b}}$ & $97.50 \pm 0.05^{\mathrm{d}}$ & $97.45 \pm 0.17^{\mathrm{d}}$ & $97.74 \pm 0.17^{\mathrm{c}}$ \\
$\mathrm{a}^{*}$ value & $-2.44 \pm 0.39^{\mathrm{a}}$ & $-4.18 \pm 0.07^{\mathrm{b}}$ & $-6.16 \pm 0.27^{\mathrm{c}}$ & $-9.61 \pm 0.28^{\mathrm{d}}$ & $-10.98 \pm 0.38^{\mathrm{e}}$ \\
$\mathrm{b}^{*}$ value & $6.63 \pm 0.97^{\mathrm{e}}$ & $13.32 \pm 0.16^{\mathrm{d}}$ & $22.23 \pm 1.05^{\mathrm{c}}$ & $33.23 \pm 0.79^{\mathrm{b}}$ & $37.32 \pm 0.42^{\mathrm{a}}$ \\
\hline
\end{tabular}

${ }^{1)}$ Means \pm SD ( $\left.n=3\right)$ in the same row followed by same letter are not significantly different by Duncan's multiple range test $(\mathrm{p}<0.05)$. 
및 색도가 선형적으로 높아지는 것으로 나타나 유자 과피를 담금 비율이 $5 \%$ 에서 $45 \%$ 까지 증가할수록 침출주의 적정 이용한 침출주 제조에 적합한 과피의 담금 비율은 $45 \%$ 이상인 것으로 판단된다. 이러한 결과는 향후 유자 과피를 활용한 고품질 침출주 제조 최적조건 확립에 기여할 것으로 보이고, 또한 상품화를 위해서는 소비자의 기호도를 고려 한 감미료 첨가 효과와 법률적 문제 관련 추가 연구가 필요 할 것으로 생각된다.

\section{요 약}

유자 과피를 이용한 침출주(liqueur) 제조에 필요한 기본 정보를 얻기 위하여, 침출용매의 에탄올 농도와 과피의 담 금 비율이 침출주의 이화학적 품질특성에 미치는 영향을 조사하였다. 유자 과실로부터 과피만을 분리, 세절하고 일 정량 $(25 \%$ 담금 비율)을 $10 \%, 20 \%, 30 \%, 40 \%, 50 \%$ 에탄올 농도의 침출용매와 혼합하거나 침출용매( $30 \%$ 에탄올) 대 비 $5 \%, 15 \%, 25 \%, 35 \%, 45 \%$ 의 담금 비율로 혼합하여 $20{ }^{\circ} \mathrm{C}$ 에서 30 일간 침출한 다음 각 침출액의 품질특성을 분석하 였다. 침출용매의 에탄올 농도가 증가함에 따라 유자 과피 침출주의 가용성 고형분과 총 비타민 $\mathrm{C}$ 함량은 약간 감소하 는 경향을, 총 페놀 함량은 약간 증가하는 경향을 각각 나타 내었다. 유자 과피의 담금 비율이 증가함에 따라 침출주의 가용성 고형분 함량, 적정산도, 총 페놀 함량, 총 비타민 $\mathrm{C}$ 함량, 항산화능 및 색도(- $\mathrm{a}^{*}$ 값, $\mathrm{b}^{*}$ 값)가 선형적으로 증가 함을 보였다. 이로써 유자 과피를 이용한 침출주 제조가 가능하였고 그의 이화학적 품질특성에 침출용매의 에탄올 농도와 과피의 담금 비율이 미치는 영향이 규명되었으며, 침출주 제조에 침출용매( $30 \%$ 에탄올) 대비 과피 담금 비율 이 $45 \%$ 이상 조건이 적합한 것으로 확인되었다.

\section{References}

1. Lee YH, Na JH (2012) Citron tea exports state and quality standardization. Food Sci Ind, 45, 44-54

2. Yang J, Jeon H, You YH, Kim JY, Choi HK, Choi KC, Jun WJ, Yoon HG (2015) Citrus ethanol extracts promotes innate immune response by activating NF- $\mathrm{kB}$. J Korean Soc Food Sci Nutr, 44, 1256-1263

3. Kim DS, Kim DH, Oh MJ, Lee KG, Kook MC, Park CS (2010) Antiaging and whitening activities of ethanol extract of Yuza (Citrus junos SIEB ex TANAKA) by-product. J Soc Cosmet Scientists Korea, 36, 137-143

4. Shin JH, Lee SJ, Seo JK, Cheon EW, Sung NJ (2008) Antioxidant activity of hot-water extract from Yuza
(Citrus junos SIEB ex TANAKA) peel. J Life Sci, 18, 1745-1751

5. Kim TW, Kim KK, Kang YH, Kim DJ, Choe M (2014) Fatty acid analysis and regulatory effects of citron (Citrus junos Sieb. ex TANAKA) seed oil on nitric oxide production, lipid accumulation, and leptin secretion. J Nutr Health, 47, 221-228

6. Lee YJ, Hwang IG, Joung EM, Kim HY, Park ES, Woo KS, Jeong HS (2009) Physiological activity and antiproliferation effects of citron seed extracts on cancer cells. J Korean Soc Food Sci Nutr, 38, 1672-1678

7. Woo KS, Jeong JY, Hwang IG, Lee YJ, Lee YR, Park HJ, Park ES, Jeong HS (2009) Antioxidant activity of ethanol extraction on citron seed by response surface methodology. J Korean Soc Food Sci Nutr, 38, 384-390

8. Jo GS, Hwang IT, Yun BG, Suh JK (2012) Stability verification and anti-atopy efficacy on essential oil of Yuzu (Citrus junos Siebold ex Tanaka). Korean J Hort Sci Technol, 30, 58-59

9. Jeong JW, Kwon DJ, Hwang JB, Jo YJ (1994) Influence of the extraction method on quality of citron juice. Korean J Food Sci Technol, 26, 704-708

10. Kim MJ, Lee KA, Park KJ, Kang H, Kim KS (2003) Physicochemical properties and formulation of citrus juice extracted with different methods. Korean J Environ Biol, 21, 31-35

11. Kang SK, Jang MJ, Kim YD (2006) Isolation and culture conditions of Acetobacter sp. for the production of citron (Citrus junos) vinegar. Korean J Food Preserv, 13, 357-362

12. Nam HW, Hyun YH (2003) Drying of citron juice from by-product of citron tea manufacturing. Korean J Food Nutr, 16, 334-339

13. Jeong EJ, Cha YJ (2016) Development of an onion vinegar beverage containing Yuza (Citrus junos Sieb ex Tanaka) and its biological activity. J Life Sci, 26, 563-570

14. Kim KM, Lee JE, Kim JS, Choi SY, Jang YE (2014) Quality characteristics of mayonnaise with varied amounts of Yuzu juice added during the storage period. Korean J Food Preserv, 21, 799-807

15. Shin JH, Choi DJ, Kwen OC (2008) Quality characteristics of Doenjang prepared with Yuza juice. Korean J Food Cookery Sci, 24, 198-205

16. Yoo KM, Seo WY, Seo HS, Kim WS, Park JB, Hwang I (2004) Physicochemical characteristics and storage stabilities of sauces with added Yuza (Citrus Junos) juice. Korean J Food Cookery Sci, 20, 403-408 
17. Nam HW, Hyun YH, Pyun JW (2004) A study on the optimum ratio of starch and dilution factors of Yuza extract in preparation of Yuza Pyun. J East Asian Soc Dietary Life, 14, 591-597

18. Kim SH, Choi DJ, Shin JH, Lee JY, Sung NJ (2004) Nutritional characteristics of ice cream added with citron (Citrus junos Sieb ex Tanaka) juice. Korean J Food Nutr, 17, 212-219

19. Kim IC (1999) Manufacture of citron jelly using the citron-extract. J Korean Soc Food Sci Nutr, 28, 396-402

20. Park SM, Lee HH, Chang HC, Kim IC (2001) Extraction and physicochemical properties of the pectin in citron peel. J Korean Soc Food Sci Nutr, 30, 569-573

21. Ji EJ, Yoo KM, Park JB, Hwang IK (2008) Preparation of citron peel tea containing Yuza (Citrus junos Seib ex TANAKA) and its antioxidant characteristics. Korean J Food Cookery Sci, 24, 460-465

22. Yang HS, Hwang SJ, Lee SH, Eun JB (2011) Fermentation characteristics and sensory characteristics of Makgeolli with dried citron (Citrus junos SIEB ex TANAKA) peel. Korean J Food Sci Technol, 43, 603-610

23. Jin TY, Wang MH, Yin Y, Eun JB (2008) Effect of Citrus junos peel on the quality and antioxidant activity of traditional rice wine, Jinyangju. J Korean Soc Food Sci Nutr, 37, 76-82

24. Kim HY, Kong HJ (2006) Preparation and quality characteristics of sugar cookies using citron powder. Korean J Food Cookery Sci, 23, 712-719

25. Lee JR, Jung JD, Hah YJ, Lee JW, Lee JI, Lee JD, Park GB, Kwack SJ (2005) Effects of addition of citron peel powder on the proximate composition, minerals, vitamin A, C content and fatty acid composition of emulsion-type sausage. J Anim Sci Technol, 47, 99-106

26. Jeong JW, Lee YC, Lee KM, Kim IH, Lee MS (1998) Manufacture condition of oleoresin using citron peel. Korean J Food Sci Technol, 30, 139-145

27. Lee SJ, Chun BS (2002) Extraction of volatile essential oil from Citrus junos peel by supercritical carbon dioxide. Korean J Biotechnol Bioeng, 17, 148-152

28. Jang MS, Kim NY (1997) Physicochemical and microbiological properties of Dongchimi added with citron (Citrus junos). Korean J Soc Food Sci, 13, 286-292

29. Yoo KM, Lee CH, Hwang IK (2008) Preparation of chocolate added with Yuza (Citrus junos Seib ex TANAKA) and its antioxidant characteristics. Korean J Food Cookery Sci, 24, 222-227

30. Kim JW, Lee GH, Hur JW (2006) Quality characteristics of citron jam made with frozen citron in Korea. Korean J Food Sci Technol, 38, 197-201

31. Yoon J, Kim H (2003) Effect of xylitol and erythritol on the quality characteristics of Yuza tea. Korean J Food Cookery Sci, 19, 737-744

32. Lee YS, Kim AJ, Rho JO (2008) Quality characteristics of sprouted brown rice Dasik with Yujacheong added. Korean J Food Cookery Sci, 24, 494-500

33. Lee JS, Hong JS (2005) The quality characteristics of Sulgidduk with the addition of citron preserved in sugar. Korean J Food Cookery Sci, 21, 851-858

34. Lee SH, Yang YT, Koh JS (2006) Changes of major constituents by soaking of kumquats and Citrus platymama with ethanol solution. Korean J Food Preserv, 13, 389-396

35. Crupi ML, Costa R, Dugo P, Dugo G, Mondello L (2007) A comprehensive study on the chemical composition and aromatic characteristics of lemon liquor. Food Chem, 105, 771-783

36. Choi IW, Baek CH, Woo SM, Lee OS, Yoon KY, Jeong YJ (2006) Establishment of optimum extraction condition for the manufacture of kiwi liqueur. Korean J Food Preserv, 13, 369-374

37. Park LY, Chae MH, Lee SH (2007) Effect of ratio of Maesil (Prunus mume) and alcohol on quality changes of Maesil liqueur during leaching and ripening. Korean J Food Preserv, 14, 645-649

38. Kwon DJ, Choi SY (2007) The effect of Deodeok contents on the quality of Deodeok wine. Korean J Food Preserv, 14, 414-418

39. Cho EK, Kim GW, Kang KO, Son JY (2018) Quality characteristics and antioxidant activities of liquor containing rose, camellia, and cockscomb. J East Asian Soc Diet Life, 28, 101-111

40. Min YK, Jeong HS (1995) Manufacture of some Korean medicinal herb liquors by soaking. Korean J Food Sci Technol, 27, 210-215

41. Kang JE, Park SK, Guo TJ, Kang JY, Lee DS, Kim JM, Kwon OJ, Lee U, Heo HJ (2016) Antioxidant activity and comparative analysis of major functional compounds in liqueur using coffee and coffee-ground. Korean J Food Preserv, 23, 560-567

42. Singleton VL, Rossi JA (1965) Colorimetry of total phenolics with phosphomolybdic-phosphotungstic acid regents. Am J Enol Vitic, 16, 144-158

43. Roe HJ, Osterling MJ (1944) The determination of dehydroascorbic acid and ascorbic acid in plant tissues 
by the 2,4-dinitrophenylhydrazine method. J Biol Chem, $152,511-517$

44. Blois MS (1958) Antioxidant determination by the use of a stable free radical. Nature, 181, 1199-1200

45. Won BY, Shin KY, Ha HJ, Yun YS (2015) Changes in nutritional composition of dropwort (Oenanthe javanica) ethanol extracts. J Korean Soc Food Sci Nutr, 44, 882-887

46. Jeong HJ, Park SB, Kim S, Kim HK (2007) Total polyphenol content and antioxidative activity of wild grape (Vitis coignetiae) extracts depending on ethanol concentrations. J Korean Soc Food Sci Nutr, 36, 1491-1496
47. Hwang SH, Kim MJ, Kim KS (2013) Biochemical properties, volatile compounds and total phenol contents of Yuza variety. Korean J Food Nutr, 26, 685-692

48. Lee SJ, Shin JH, Kang MJ, Jeong CH, Ju JC, Sung NJ (2010) Physicochemical properties, free sugar and volatile compounds of Korean citrons cultivated in different areas. J Korean Soc Food Sci Nutr, 39, 92-98 